\title{
Crystal Structure, Supramolecular Self-Assembly and Interaction with DNA of a Mixed Ligand Manganese(II) Complex
}

\author{
Yun-Ming Sun, ${ }^{a}$ Feng-Ying Dong, ${ }^{*, a, b}$ Da-Qi Wang ${ }^{c}$ and Yan-Tuan Li ${ }^{b}$ \\ ${ }^{a}$ College of Chemistry and Pharmacy, Qingdao Agricultural University, Qingdao, Shandong, \\ 266109, People's Republic of China \\ ${ }^{b}$ Marine Drug \& Food Institute, Ocean University of China, 5 Yushan Road, Qingdao, Shandong, \\ 266003, People's Republic of China \\ ${ }^{c}$ College of Chemistry and Chemical Engineering, Liaocheng University, Liaocheng, Shandong, \\ 252059, People's Republic of China
}

\begin{abstract}
Um complexo misto de manganês(II), $\left[\mathrm{Mn}(\mathrm{sal})(\text { phen })_{2}\right] \mathrm{ClO}_{4}(\mathbf{1})(\mathrm{sal}=$ salicilaldeído, phen $=$ 1,10-fenantrolina), foi sintetizado e caracterizado por análise elementar e difração de raio-X de monocristais. A análise dos difratogramas revelou que o complexo $\mathbf{1}$ cristaliza no grupo espacial monoclínico $P 2_{1} / \mathrm{n}$. A unidade assimétrica do complexo é composta do cátion complexo $\left[\mathrm{Mn}(\mathrm{sal})(\mathrm{phen})_{2}\right]^{+}$e do ânion perclorato não coordenado. O manganês(II) está num ambiente de coordenação $\mathrm{MnN}_{4} \mathrm{O}_{2}$ de geometria octaédrica bem distorcida. Quatro tipos de empilhamento $\pi-\pi$ envolvendo ligantes fenantrolina e salicilaldeído estão envolvidos na auto-montagem supramolecular. Estas interações de empilhamento aromático cooperam com ligações de hidrogênio para a montagem de uma fascinante arquitetura supramolecular 3D com o complexo. Estudos de espectroscopia de absorção eletrônica e de titulação monitorando-se a fluorescência de $\mathbf{1}$ com DNA de timo de bezerro sugerem a ligação do complexo por intercalação com uma constante de formação igual a $7,97 \times 10^{3} \mathrm{~L} \mathrm{~mol}^{-1}$ e uma constante de supressão de Stern-Volmer de $1,34 \times 10^{4} \mathrm{~L} \mathrm{~mol}^{-1}$.
\end{abstract}

A mixed ligand manganese(II) complex, $\left[\mathrm{Mn}(\mathrm{sal})(\mathrm{phen})_{2}\right] \mathrm{ClO}_{4}(\mathbf{1})(\mathrm{sal}=$ salicylaldehyde, phen $=1,10$-phenanthroline), has been synthesized and characterized by elemental analysis and single crystal X-ray diffractometry. The structural analysis revealed that complex $\mathbf{1}$ crystallizes in the monoclinic space group $P 2_{1} / \mathrm{n}$. The asymmetric unit of the complex is comprised of $\left[\mathrm{Mn}(\mathrm{sal})(\mathrm{phen})_{2}\right]^{+}$complex cation and uncoordinated perchlorate anion. The manganese(II) is located in a seriously distorted octahedral $\mathrm{MnN}_{4} \mathrm{O}_{2}$ coordination environment. Four types of $\pi-\pi$ stacking modes involving phenanthroline and salicylaldehyde ligands are involved in the supramolecular self-assembly. These aromatic stacking interactions cooperate with hydrogen bonding to assemble the complex into a fascinating 3D supramolecular architecture. Electronic absorption spectroscopy and fluorescence titration studies of the interaction between complex $\mathbf{1}$ and calf thymus DNA suggest an intercalative binding mode with a constant of $7.97 \times 10^{3} \mathrm{~L} \mathrm{~mol}^{-1}$ and a Stern-Volmer quenching constant of $1.34 \times 10^{4} \mathrm{~L} \mathrm{~mol}^{-1}$.

Keywords: manganese(II) complex, crystal structure, supramolecular self-assembly, DNA interaction, spectrum

\section{Introduction}

Much attention has been given to rational design, synthesis and characterization of new transition metal complexes in the past decades because some of them can interact with DNA acting as probes for nucleic acid structure

*e-mail: dfy1972@163.com manipulation or exhibiting nuclease property. ${ }^{1-5}$ Metal complex can bind to DNA in non-covalent way such as by electrostatic interaction, minor or major groove-bound fashion and intercalation. ${ }^{6,7}$ Considerable efforts are yet necessary to develop novel metal complexes binding to DNA through an intercalative association because of their unique properties and applications. ${ }^{8-13} \mathrm{~A}$ metallointercalator binds DNA through the insertion of a planar polycyclic aromatic 
ligands, $\pi$-stacking in between two base pairs. ${ }^{14,15}$ So the binding site and the intensity of a metallointercalator can be tuned by the metal coordination center and chelate ligand.

Manganese is an essential element and plays a critical role in a number of physiologic processes as a constituent or activator of some enzymes. ${ }^{16}$ It is well established that manganese complexes are present in redox enzymes such as manganese superoxide dismutase, glycosyltransferase and in the metabolism of carbohydrates, amino acids and cholesterol. ${ }^{17,18}$ Some manganese complexes, e.g. $[\mathrm{Mn}(\mathrm{TMPyP})](\mathrm{OAc})_{5}$ $(\mathrm{TMPyP}=$ meso-tetrakis(4- $N$-methylpyridinumyl) porphyrinato), ${ }^{19}$ manganese-salen derivatives, ${ }^{20,21}[\mathrm{Mn}(\mathrm{L})$ $\left.\left(\mathrm{NO}_{3}\right)_{2}\left(\mathrm{H}_{2} \mathrm{O}\right)_{2}\right](\mathrm{L}=2 \mathrm{H}$-5-hydroxy-1,2,5-oxadiazo[3,4-f] 1,10-phenanthroline $)^{22}$ and $\left[\mathrm{MnL}\left(\mathrm{NO}_{3}\right)\left(\mathrm{H}_{2} \mathrm{O}\right)_{3}\right] \mathrm{NO}_{3} \cdot \mathrm{CH}_{3} \mathrm{OH}$ ( $\mathrm{L}=6,7$-dicycanodipyrido[2,2- $\left.d: 2^{\prime}, 3^{\prime}-f\right]$ quinoxaline), ${ }^{23}$ also present intercalative DNA-binding capacity or significant DNA/antitumor activity. Therefore the synthesis and characterization of new manganese complexes are of great importance not only for developing novel chemotherapeutics and highly sensitive diagnostic agents but also for understanding the role and mechanism of manganese complexes in biological system. In this study a mixed ligand manganese(II) complex, $\left[\mathrm{Mn}(\mathrm{sal})(\mathrm{phen})_{2}\right] \mathrm{ClO}_{4}(\mathbf{1})(\mathrm{sal}=$ salicylaldehyde, phen $=1,10$-phenanthroline), is reported. The crystal structure, non-covalent interactions and the 3D supramolecular self-assembly are discussed. The spectral behavior of the complex interacting with calf thymus DNA (CT-DNA) is explored by electronic absorption and fluorescence emission measurements.

\section{Experimental}

\section{Materials and methods}

Calf thymus DNA was purchased from the Sigma Company. All other chemicals and solvents were acquired from commercial sources and used as received, unless otherwise noted. Tris- $\mathrm{HCl}$ buffer solution $(\mathrm{pH} 7.66$, Tris $=$ tris(hydroxymethyl)aminomethane) was prepared using redistilled water.

The $\mathrm{C}, \mathrm{H}$ and $\mathrm{N}$ microanalyses were performed on a Perkin-Elmer 240 elemental analyzer. The electronic spectrum was measured on a Cary 300 spectrophotometer. The fluorescence spectra were measured with a FP-6200 fluorescence spectrophotometer.

\section{Preparation of $\left[\mathrm{Mn}(\right.$ sal $\left.)(\text { phen })_{2}\right] \mathrm{ClO}_{4}(\mathbf{1})$ complex}

A stock solution $(10 \mathrm{~mL})$ of $\mathrm{Mn}\left(\mathrm{ClO}_{4}\right)_{2} \cdot 6 \mathrm{H}_{2} \mathrm{O}$ (723.9 $\mathrm{mg}, 2 \mathrm{mmol}$ ) in ethanol was added into $10 \mathrm{~mL}$ of a 1,10-phenanthroline monohydrate solution $(396.4 \mathrm{mg}$, $2 \mathrm{mmol})$ in ethanol. Then an aqueous solution $(20 \mathrm{~mL})$ of salicylaldehyde (268.6 mg, $2.2 \mathrm{mmol}$ ) and $\mathrm{NaOH}(88.0 \mathrm{mg}$, $2.2 \mathrm{mmol}$ ) was added dropwise and the mixture was stirred for $3 \mathrm{~h}$ at room temperature. Then, the orange precipitate was collected, washed with ethanol and air-dried. A bright orange crystal of $\left[\mathrm{Mn}(\mathrm{sal})(\mathrm{phen})_{2}\right] \mathrm{ClO}_{4}$ suitable for X-ray determination was obtained in a home-made $\mathrm{V}$-shaped tube filled with a 1:1 mixture of acetonitrile and ethanol. Yield, 78\% (based on phenanthroline). Anal. Calc. for $\mathrm{C}_{31} \mathrm{H}_{21} \mathrm{ClMnN}_{4} \mathrm{O}_{6}: \mathrm{C}, 58.55 ; \mathrm{H}, 3.33 ; \mathrm{N}, 8.81$. Found: C, $58.51 ; \mathrm{H}, 3.30 ; \mathrm{N}, 8.78$.

\section{Determination of X-ray crystal structure}

The X-ray diffraction experiment for complex $\mathbf{1}$ was carried out on a Bruker Smart-1000 CCD diffractometer with graphite monochromated $\mathrm{Mo} \mathrm{K}_{\alpha} \alpha(\lambda=0.71073 \AA)$ radiation at room temperature. Data collection, cell refinement, data reduction and correction for absorption were performed using Bruker programs. ${ }^{24}$ The structure was solved by direct method and expanded using the Fourier transform package in Shelxl-97 program. ${ }^{25}$ The nonhydrogen atoms were refined anisotropically by full-matrix least-square calculations on $F^{2}$. The $\mathrm{C}$-bound $\mathrm{H}$ atoms were placed in calculated positions, with $\mathrm{C}-\mathrm{H}$ distance of $0.93 \AA$, and refined as riding, with $\mathrm{U}_{\text {iso }}(\mathrm{H})=1.2 \mathrm{U}_{\mathrm{eq}}(\mathrm{C})$. Detailed information about crystal data and structure determinations is summarized in Supplementary Information (Table S1).

\section{Interaction of complex with DNA}

All experiments involving CT-DNA were performed in Tris-HCl buffer solution. Stock solution of the CTDNA was stored at $4{ }^{\circ} \mathrm{C}$ and used in no more than four days. The ratio of UV absorbance at 260 and $280 \mathrm{~nm}$ is about 1.9 , which indicates that the DNA was sufficiently independent of protein in the buffer. ${ }^{26}$ The CT-DNA concentration was determined spectrophotometrically using the molar absorptivity of $6600 \mathrm{~L} \mathrm{~mol}^{-1} \mathrm{~cm}^{-1}$ at $260 \mathrm{~nm}^{27}$ Concentrated stock solution of complex $\mathbf{1}$ was prepared in DMF and the solution was diluted with Tris-HCl buffer. Spectrophotometric titration was performed by adding increments of the CT-DNA to the complex solution and incubating for $10 \mathrm{~min}$ before recording the signal. The fluorescence titration experiment was performed by keeping the concentration of complex $\mathbf{1}$ constant while increasing the CT-DNA concentration. The fluorescence spectra of complex 1 were recorded exciting at $254 \mathrm{~nm}$ and monitoring at $366 \mathrm{~nm}$. Fluorescence quenching experiments were carried out with CT-DNA pretreated with ethidium 
bromide (EB) in the dark for at least $2 \mathrm{~h}$. Increasing amounts of complex solution were added to the pretreated CT-DNA solution and their effect on emission intensity was measured. The ethidium bromide displacement spectra were recorded exciting at $522 \mathrm{~nm}$ and monitoring at $583 \mathrm{~nm}$.

\section{Results and Discussion}

\section{Description of the crystal structure}

The asymmetric cell of complex $\mathbf{1}$ is comprised of $\left[\mathrm{Mn}(\mathrm{sal})(\mathrm{phen})_{2}\right]^{+}$complex cation and uncoordinated perchlorate anion. The Oak Ridge thermal ellipsoid plot of complex cation is depicted in Figure 1. Complex $\mathbf{1}$ crystallizes in the monoclinic space group $P 2_{1} / \mathrm{n}$. In $\left[\mathrm{Mn}(\mathrm{sal})(\mathrm{phen})_{2}\right]^{+}$complex cation, $\mathrm{Mn}(\mathrm{II})$ is coordinated by two $\mathrm{O}$ atoms from one salicylaldehyde and four $\mathrm{N}$ atoms from two phenanthroline ligands. Four atoms, N1, $\mathrm{N} 2, \mathrm{~N} 4$ and $\mathrm{O} 2$ are located at the equatorial plane with the mean deviation of $0.144 \AA$. The manganese center is only $0.062 \AA$ displaced from the equatorial plane. The $\mathrm{Mn}-\mathrm{N} / \mathrm{O}$ bond lengths and N/O-Mn-N/O bond angles range from $2.057(4)$ to $2.346(5) \AA$, and from $71.69(17)$ to $160.36(17)^{\circ}$ (Table S2), indicating that $\mathrm{Mn}$ (II) is located in a seriously distorted octahedral coordination environment. ${ }^{28-30}$ Perchlorate anion is not directly coordinated to the metal center but forms a series of hydrogen bonds in the supramolecular structure.

Non-covalent interactions and supramolecular selfassembly

Crystal structure analysis and calculation revealed abundant non-covalent interactions such as $\pi-\pi$ stacking interactions and hydrogen bonds in complex $\mathbf{1}$. The stacking interactions as well as hydrogen bonds are essential for the structural stability and function of DNA and RNA and for self-assembly or recognition processes when extended structures are formed from building blocks with aromatic moieties. ${ }^{31-34}$ Our previous studies demonstrate that 1,10-phenanthroline is one of the most favorable bidentate ligands to display $\pi$ - $\pi$ stacking supramolecular interactions in the crystal due to its large aromatic system. ${ }^{35}$ As dealt with before, ${ }^{36,37}$ two stacking phenanthroline molecules are divided into four pyridine (A, $\mathrm{A}^{\prime}, \mathrm{C}$ and $\mathrm{C}^{\prime}$ ) and two arene (B and $\mathrm{B}^{\prime}$ ) segments in order to facilitate the description of this extended $\pi$ system. The corresponding stacking data such as the interplanar separation (h), dihedral angle $(\alpha)$, centroid-centroid distance (d), centroid displacement (r) and slip angle $(\theta)$ were calculated (Table S3). The analysis of stacking data indicates four types of intermolecular $\pi-\pi$

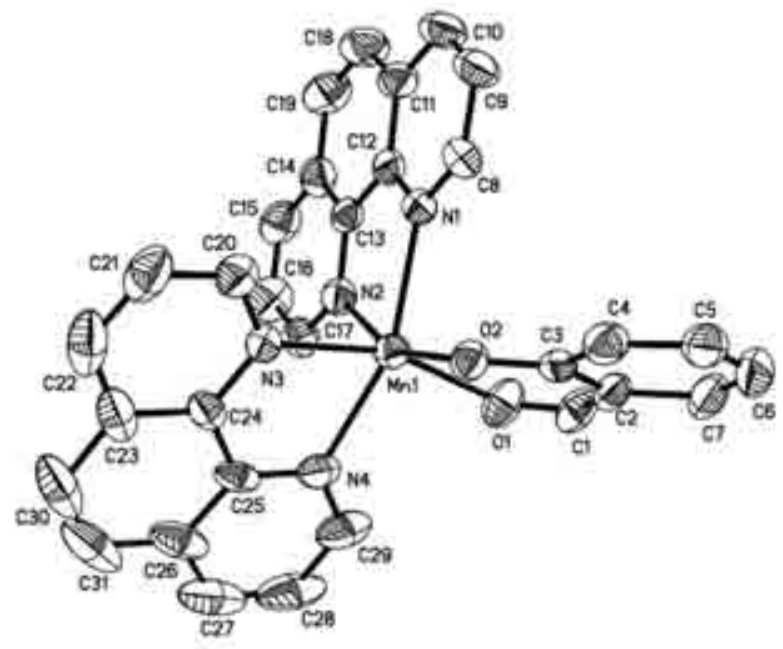

Figure 1. ORTEP structure of complex cation $\left[\mathrm{Mn}(\mathrm{sal})(\mathrm{phen})_{2}\right]^{+}$in complex 1 with $20 \%$ probability ellipsoids. Hydrogen atoms are omitted for clarity.

stacking modes, i.e. (I) phenanthroline-phenanthroline (phen-phen), (II) pyridine-pyridine (py-py), (III) pyridinearene (py-ar) offset face-to-face and (IV) T-shaped stacking were observed in complex 1 (Figure 2). As illustrated in Figure 2a, two N4-bound phenanthroline (N4-phen) molecules (symmetry codes: $2-\mathrm{x}, 2-\mathrm{y},-\mathrm{z}$ ) give an opposite orientation in stacking mode I. They are parallel to each other with the interplanar separation of $3.520 \AA$. The centroid-centroid distances of $\mathrm{A}-\mathrm{C}^{\prime}, \mathrm{C}-\mathrm{A}^{\prime}, \mathrm{B}-\mathrm{C}^{\prime}, \mathrm{B}-\mathrm{B}^{\prime}$, $\mathrm{C}-\mathrm{B}^{\prime}$ and $\mathrm{C}-\mathrm{A}^{\prime}$ all fall in the 3.63-4.00 $\AA$ range, which indicates the $\pi-\pi$ interactions involve the extended $\pi$ system of whole phenanthroline molecule. For two stacking phenanthroline molecules, the centroid displacement is $1.23 \AA$ and the slip angle is $19.32^{\circ}$, similar to those of a perfect face-to-face alignment. Such phenanthrolinephenanthroline stacking mode is rare in the reported complexes. $^{38}$ Two N1-bound phenanthroline molecules (symmetry codes: $1.5-\mathrm{x}, 0.5+\mathrm{y}, 0.5-\mathrm{z}$ ) stack with each other to give stacking mode II (Figure 2b). The stacking parts are not completely parallel to each other but inclined with the dihedral angle of $11^{\circ}$. Other centroid-centroid distances among the six-membered rings are all longer than $4.0 \AA$ except $\mathrm{A}^{\prime}-\mathrm{C}$ for $3.787 \AA$, suggesting $\pi-\pi$ stacking interactions mainly occur in two outer pyridine rings. This mode is comparable to pyridine-pyridine-type approach of stacked quinoline molecules.$^{38}$ Owing to the large centroid displacement $(1.44 \AA)$ and slip angle $\left(22.29^{\circ}\right)$, the stacking force in complex $\mathbf{1}$ is apparently weaker than that in the $\left\{[\mathrm{Cu} \text { (phen) } \mathrm{CN}][\mathrm{Cu} \text { (phen) }]\left[\mathrm{Cu}(\mathrm{CN})_{2}\right]\right\}_{n}$ complex..$^{35}$ The complex cations are organized into a ladder-like chain through the $\pi-\pi$ stacking interactions I and II (Figure 3a).

Another two types of $\pi-\pi$ stacking interactions (mode III and IV) involving phenanthroline and salicylaldehyde 
(a)

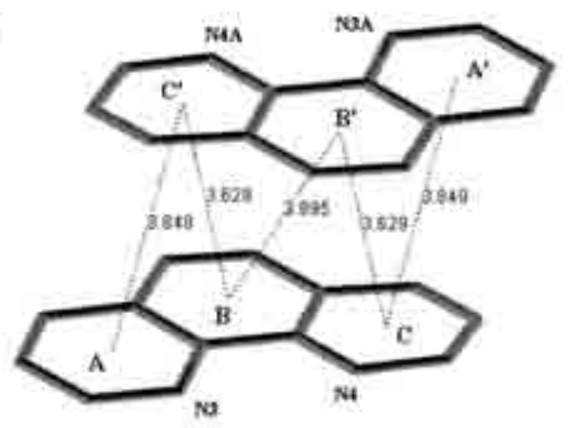

(b)

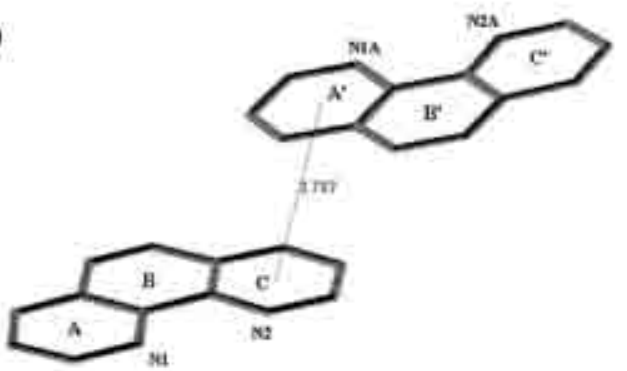

(c)

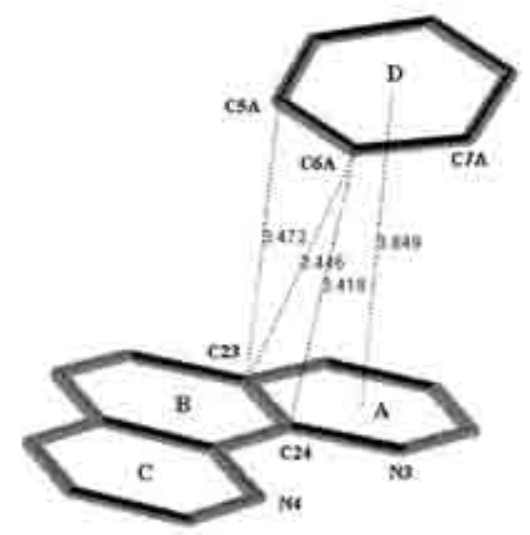

(d)

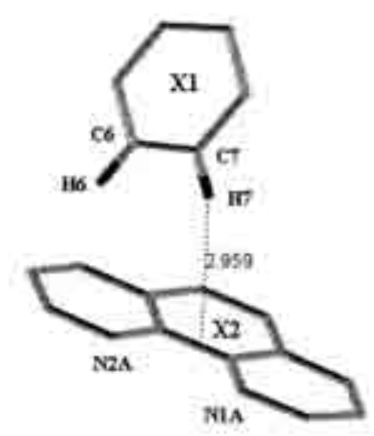

Figure 2. Stacking modes of $\pi-\pi$ interactions in complex 1. (a) Mode I (symmetry codes: 2-x, 2-y, $-\mathrm{z}$ ). (b) Mode II (symmetry codes: $1.5-\mathrm{x}$, $0.5+y, 0.5-z)$. (c) Mode IIII (symmetry codes: $0.5+x, 1.5-y,-0.5+z$ ). (d) Mode IV (symmetry codes: $0.5+x, 1.5-y, 0.5+z)$.

are observed besides the above-mentioned stacking interactions between phenanthroline ligands. As shown in Figure 2c, the stacking mode III involves one pyridine ring of N3-bound phenanthroline and one aromatic ring of salicylaldehyde. Although two $\pi$ systems present the large

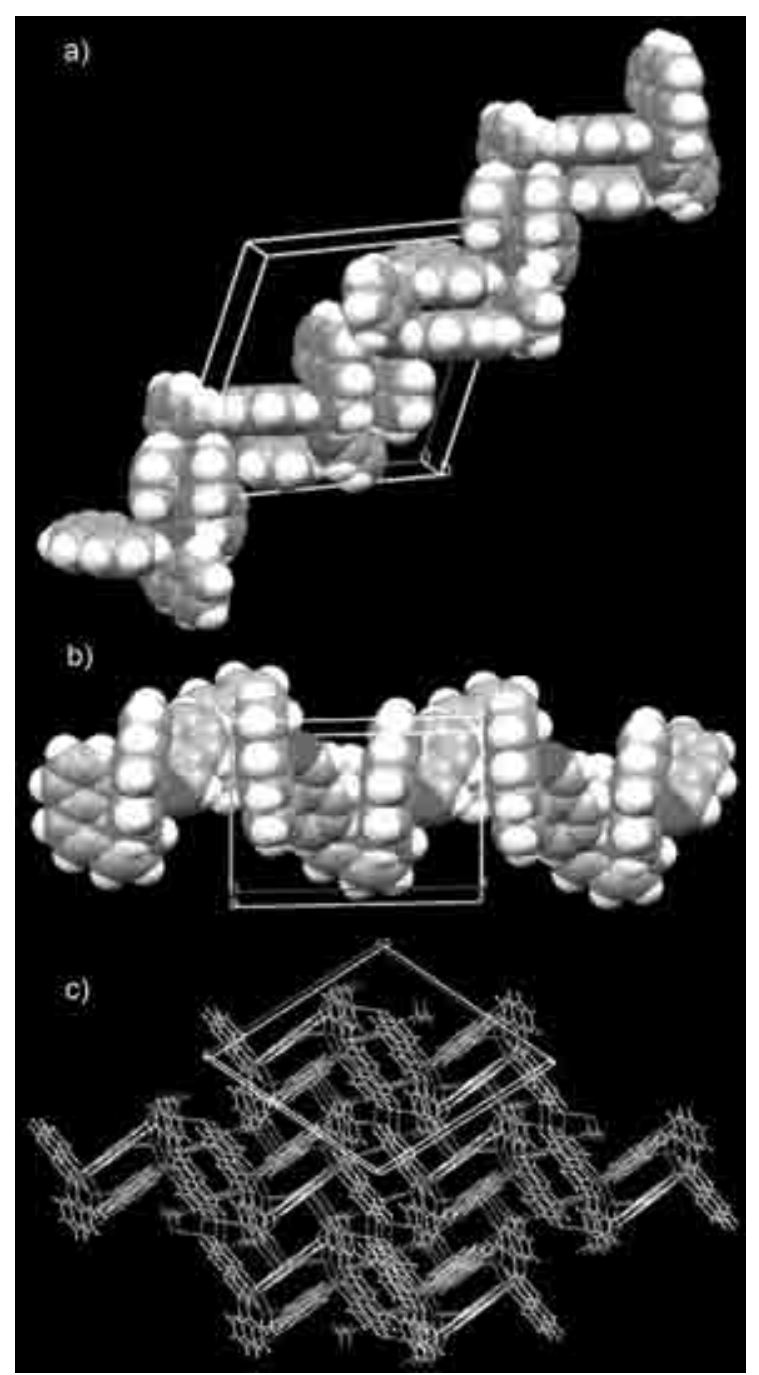

Figure 3. The supramolecular self-assembly architecture of complex $\mathbf{1}$. (a) The ladder-like chain formed by complex cations through $\pi-\pi$ stacking mode I and II. (b) The quasi-helical chain formed by complex cations through $\pi-\pi$ stacking mode III and IV. (c) The 3D supramolecular construction by means of $\pi-\pi$ stacking interactions and hydrogen bonds.

dihedral angle $\left(17.6^{\circ}\right)$, interplanar separation $(3.721 \AA)$ and centroid-centroid distance $(3.849 \AA)$, some short

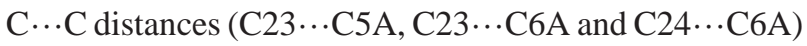
bear out the severely offset $\pi$-stacked geometry with an aromatic attraction rather than a $\pi-\pi$ repulsion. ${ }^{39}$ The stacked geometry of mode IV is very distinct from that of the above three (Figure 2d). Two stacked aromatic systems, C7-bound arene ring of salicylaldehyde and N1A-bound phenanthroline (symmetry codes: $0.5+x, 1.5-y$, $0.5+\mathrm{z}$ ), do not assume parallel or near parallel face-to-face arrangement but almost perpendicular with the dihedral angle of $95^{\circ}$. The distances of $\mathrm{H7}$ atom-centroid $(2.970 \AA)$, H6 … $17 \mathrm{~A}(2.852 \AA)$ and $\mathrm{H} 7 \cdots \mathrm{C} 13 \mathrm{~A}(2.887 \AA)$ are all smaller than the observed value (3.02 $\AA$ ), making it clear that mode IV is a typical edge-to-face, namely T-shaped arrangement. ${ }^{40}$ Such edge-to-face stacking systems are 
mainly dominated by $\pi-\delta$ attraction and more stable than offset face-to-face arrangement. ${ }^{39}$ As displayed in Figure $3 \mathrm{~b}$, the complex cations are assembled into a quasi-helical chain along the crystallographic $c$ axis through $\pi-\pi$ stacking action III and IV.

In addition, four $\mathrm{O}$ atoms, two of them from salicylaldehyde and others from perchlorate, form six weak $\mathrm{C}-\mathrm{H}$... O hydrogen bonds with $\mathrm{C}-\mathrm{H}$ bonds of phenanthroline and salicylaldehyde (Table S4). This $\mathrm{C} 8-\mathrm{H} 8 \cdots \mathrm{O} 2$ is an intramolecular hydrogen bond and others are intermolecular. The $\mathrm{O} 1$ and $\mathrm{O} 5$ atoms produce two normal hydrogen bonds $\mathrm{C} 10-\mathrm{H} 10 \cdots \mathrm{O} 1$ (symmetry codes: $1.5-\mathrm{x}$, $-0.5+\mathrm{y}, 0.5-\mathrm{z}$ ) and $\mathrm{C} 1-\mathrm{H} 1 \cdots \mathrm{O} 5$ (symmetry codes: $0.5-\mathrm{x}$, $0.5+\mathrm{y}, 0.5-\mathrm{z}$ ). However both $\mathrm{O} 2$ and $\mathrm{O} 3$ act as $\mathrm{H}$-acceptor to participate in forming double hydrogen bonds, respectively, i.e., $\mathrm{C} 8-\mathrm{H} 8 \cdots \mathrm{O} 2, \mathrm{C} 31-\mathrm{H} 31 \cdots \mathrm{O} 2$ (symmetry codes: $1-\mathrm{x}$,

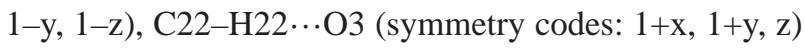
and $\mathrm{C} 29-\mathrm{H} 29 \cdots \mathrm{O} 3$ (symmetry codes: $1-\mathrm{x}, 1-\mathrm{y},-\mathrm{z}$ ). ${ }^{41}$ Because two roughly parallel donor dipoles repel each other, the double hydrogen bonds may influence each other and reduce their strengths..$^{42}$ These intermolecular hydrogen bonds cooperate with $\pi-\pi$ stacking action to assemble complex $\mathbf{1}$ into an interesting 3D supramolecular structure (Figure 3c).

\section{Spectrophotometric titration for DNA binding studies}

Electronic absorption spectroscopy is an effective method to determine the binding mode and intensity of metal complex with DNA. The hypochromism is associated with the intercalative binding mode involving a strong stacking interaction between the aromatic chromophore of complex and the base pairs of DNA. ${ }^{43}$ The electronic absorption spectra of complex $\mathbf{1}$ in absence and presence of CT-DNA are given in Figure 4. As the concentration of CT-DNA increased, the electronic spectra display a progressive decrease at $266 \mathrm{~nm}$, which suggests that complex 1 interacts with CT-DNA through an intercalative association in which the planar aromatic moiety slides in between base pairs by means of $\pi-\pi$ stacking interactions. ${ }^{44}$ The result can be rationally explained as follows: some $\pi^{*}$ orbitals of the aromatic ligand are coupled with $\pi$ orbitals of the base pairs when complex 1 intercalates into the base pairs of CT-DNA. The coupled orbitals are partially filled by electrons, which gives rise to the decrease of the $\pi-\pi^{*}$ transition energy and the transition probability, and shows hypochromism. ${ }^{9}$

The intrinsic binding constant $\mathrm{K}_{\mathrm{b}}$ can be obtained from the spectral titration data by equation 1 to determine quantitatively the DNA binding characteristics of complex 1:45

$$
[\mathrm{DNA}] /\left(\varepsilon_{\mathrm{a}}-\varepsilon_{\mathrm{f}}\right)=[\mathrm{DNA}] /\left(\varepsilon_{\mathrm{b}}-\varepsilon_{\mathrm{f}}\right)+1 / \mathrm{K}_{\mathrm{b}}\left(\varepsilon_{\mathrm{b}}-\varepsilon_{\mathrm{f}}\right)
$$

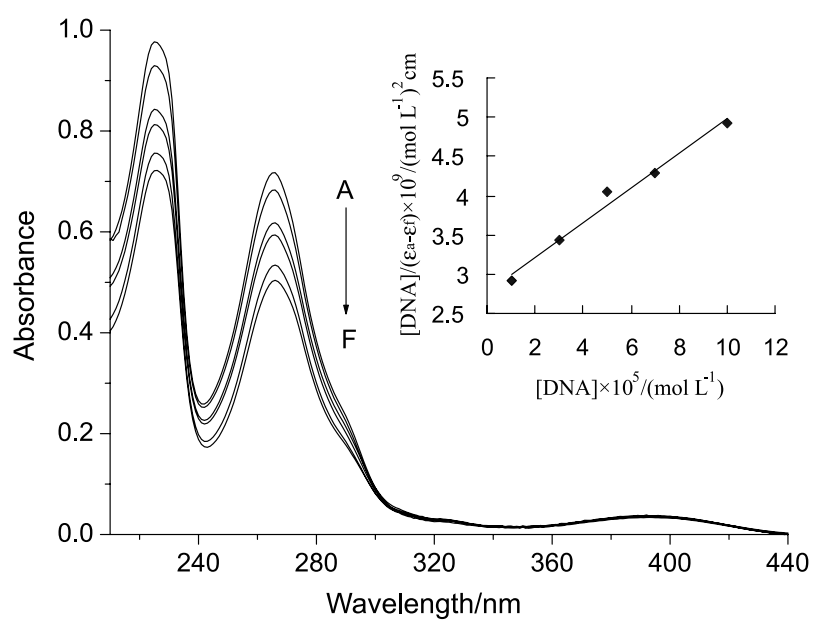

Figure 4. Absorption spectra of complex 1 in Tris- $\mathrm{HCl}$ buffer at $\mathrm{pH}=7.66$, in absence (A) and in presence of increasing amounts of [DNA] (B-F). $[$ Complex $]=1.0 \times 10^{-5} \mathrm{~mol} \mathrm{~L}^{-1}$, $[\mathrm{DNA}]=1.0-10.0 \times 10^{-5} \mathrm{~mol} \mathrm{~L}^{-1}$. Arrow shows the absorbance change trend upon increasing DNA concentration. Insert: Plot of $[D N A] /\left(\varepsilon_{a}-\varepsilon_{f}\right)$ vs. [DNA] for complex $\mathbf{1}$. The best fit line, superimposed on the data, yields $\mathrm{K}_{\mathrm{b}}=7.97 \times 10^{3} \mathrm{~L} \mathrm{~mol}^{-1}$.

where [DNA] is the concentration of CT-DNA; $\varepsilon_{\mathrm{f}}, \varepsilon_{\mathrm{a}}$ and $\varepsilon_{\mathrm{b}}$ correspond to the extinction coefficient for free, added, and fully bound to complex $\mathbf{1}$, respectively. The plot of $[D N A] /\left(\varepsilon_{a}-\varepsilon_{f}\right)$ versus [DNA] gives the $\mathrm{K}_{\mathrm{b}}$ value as the ratio of slope to intercept. From the plot shown in Figure 4, the intrinsic binding constant $\mathrm{K}_{\mathrm{b}}$ for complex $\mathbf{1}$ is calculated as $7.97 \times 10^{3} \mathrm{~L} \mathrm{~mol}^{-1}$ ( $r=0.992$ for five points) which is smaller than that of $\left[\mathrm{Co}(\mathrm{phen})_{2}(\mathrm{amtp})\right]\left(\mathrm{ClO}_{4}\right)_{3}$ $\left(3.23 \times 10^{5} \mathrm{~L} \mathrm{~mol}^{-1}\right),{ }^{46}$ indicating that it is a moderate binder of CT-DNA.

\section{Fluorescence titration experiments for DNA binding studies}

The fluorescence titration experiment has been used to characterize the interaction of complex with DNA following the changes in fluorescence intensity of complex. As shown in Figure 5a, complex $\mathbf{1}$ is fluorescent exhibiting the most intense peak at $366 \mathrm{~nm}$ in Tris- $\mathrm{HCl}$ buffer at ambient temperature. The emission intensities gradually decreased with the addition of CT-DNA, indicating an interaction with complex 1 . The quenching may be attributed to the electron transfer from the base pairs of CT-DNA to the excited MLCT state of complex. ${ }^{47}$

In order to further investigate the interaction between complex 1 and CT-DNA, the ethidium bromide (EB) fluorescence displacement experiment has been carried out. It is known that EB can emit intense fluorescence in presence of DNA due to the strong intercalation between the adjacent DNA base pairs. The fluorescence of EB-DNA system can be quenched by addition of a second species that is able to displace the EB molecules. The quenching degree 

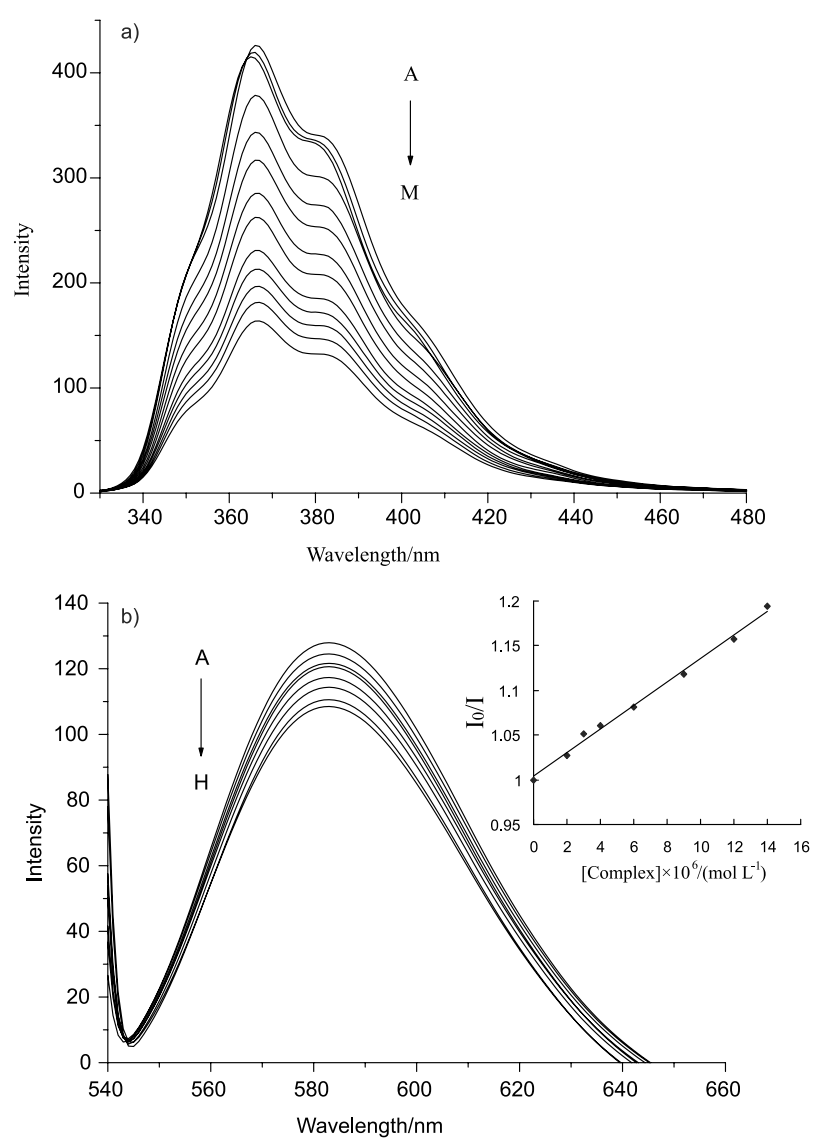

Figure 5. (a) Emission spectra of complex $\mathbf{1}$ in absence (A) and in presence of increasing amounts of [DNA] (B-M) with subtraction of the complex absorbance. $\lambda_{\mathrm{ex}}=254 \mathrm{~nm},[$ Complex $]=1.0 \times 10^{-5} \mathrm{~mol} \mathrm{~L}^{-1}$, $[D N A]=1.0-13.0 \times 10^{-5} \mathrm{~mol} \mathrm{~L}^{-1}$. Arrow shows the intensity change upon increasing DNA concentration. (b) Fluorescence quenching curves of EB bound to DNA by complex $1 . \lambda_{\text {ex }}=522 \mathrm{~nm},[\mathrm{~EB}]=1.0 \times 10^{-6} \mathrm{~mol} \mathrm{~L}^{-1}$, $[\mathrm{DNA}]=2.5 \times 10^{-5} \mathrm{~mol} \mathrm{~L}-1$, [Complex $]=0-14.0 \times 10^{-6} \mathrm{~mol} \mathrm{~L}^{-1}(\mathrm{~A}-\mathrm{H})$. Arrow shows the intensity change upon increasing the complex concentration. Insert: Plot of $\mathrm{I}_{0} / \mathrm{I}$ vs. [complex] for fluorescence quenching curves of EB bound to DNA for complex $\mathbf{1}$. The best fit line yields $\mathrm{K}_{\mathrm{sv}}=1.34 \times 10^{4} \mathrm{~L} \mathrm{~mol}^{-1}$.

of the EB-DNA system fluorescence is usually used to determine the binding strength. ${ }^{48,49}$ The fluorescence spectra of EB-DNA system in absence and presence of complex $\mathbf{1}$ are given in Figure 5b. The fluorescence intensity at $583 \mathrm{~nm}$ decreased as a function of the complex concentration, suggesting the displacement of some EB molecules from the base pairs. This behavior was analyzed using the SternVolmer equation (2): $:^{50}$

$$
\mathrm{I}_{0} / \mathrm{I}=1+\mathrm{K}_{\mathrm{sv}}[\mathrm{Q}]
$$

where $\mathrm{I}_{0}$ and I represent the fluorescence intensities in absence and presence of quencher, respectively, [Q] is the concentration of quencher, $\mathrm{K}_{\mathrm{sv}}$ is a linear SternVolmer quenching constant. In the quenching plot of $\mathrm{I}_{0} / \mathrm{I}$ versus [complex], $\mathrm{K}_{\mathrm{sv}}$ value is given by the slope. The $\mathrm{K}_{\mathrm{sv}}$ value for complex 1 was calculated as $1.34 \times 10^{4} \mathrm{~L} \mathrm{~mol}^{-1}$ ( $r=0.995$ for eight points). This is smaller than that of complex $\left[\mathrm{Co}(\text { phen })_{2}(\operatorname{amtp})\right]\left(\mathrm{ClO}_{4}\right)_{3}\left(7.75 \times 10^{5} \mathrm{~L} \mathrm{~mol}^{-1}\right),{ }^{46}$ indicating complex $\mathbf{1}$ is more weakly bound to CT-DNA. The result also matches with the spectrophotometric titration experiments.

\section{Conclusions}

A new mixed ligand manganese(II) complex [Mn(sal) (phen) $\left.{ }_{2}\right] \mathrm{ClO}_{4}$ was synthesized and its crystal structure resolved by single crystal X-ray diffraction. Some C-H...O hydrogen bonds and four types of $\pi-\pi$ stacking interaction modes involving phenanthroline and salicylaldehyde ligands were observed and discussed in detail. A fascinating 3D supramolecular structure is generated by these supramolecular non-covalent interactions. Spectroscopic studies suggest the manganese(II) complex interacts with CT-DNA by means of intercalation mechanism with moderate binding intensity. The results are valuable in understanding the binding modes of the metal complex with DNA as well as laying a foundation for rationally design of novel agents with different binding affinity for probing and targeting nucleic acids.

\section{Supplementary Information}

Crystallographic data (excluding structure factors) for the structures in this paper have been deposited in the Cambridge Crystallographic Data Centre as supplementary publication number CCDC 763705. Copies of the data can be obtained, free of charge, via www.ccdc.cam.ac.uk/conts/retrieving. html or from the Cambridge Crystallographic Data Centre, CCDC, 12 Union Road, Cambridge CB2 1EZ, UK; fax: +44 1223 336033. E-mail: deposit@ccdc.cam.ac.uk.

More information is available free of charge at http://jbcs.sbq.org.br as a pdf file.

\section{Acknowledgments}

All authors acknowledge the financial support of Qingdao Agricultural University (630916 and SYKT10-30) and Ocean University of China.

\section{References}

1. Sigman, D. S.; Graham, D. R.; D’Aurora, V.; Stern, A. M.; J. Biol. Chem. 1979, 254, 12269.

2. Aldrich-Wright, J. R.; Vagg, R. S.; Williams, P. A.; Coord. Chem. Rev. 1997, 166, 361.

3. Clarke, M. J.; Coord. Chem. Rev. 2002, 232, 69. 
4. Li, Y.; Wu, Y.; Zhao, J.; Yang, P.; J. Inorg. Biochem. 2007, 101, 283.

5. Hadjiliadis, N.; Sletten, E.; Metal Complex-DNA Interactions, Wiley-Blackwell: Hoboken, New Jersey, USA, 2009.

6. Chelli, R.; Gervasio, F. L.; Procacci, P.; Schettino, V.; J. Am. Chem. Soc. 2002, 124, 6133.

7. Keene, F. R.; Smith, J. A.; Collins, J. G.; Coord. Chem. Rev. 2009, 253, 2021.

8. Wang, B.-d.; Yang, Z.-Y.; Crewdson, P.; Wang, D.-q.; J. Inorg. Biochem. 2007, 101, 1492.

9. Jiang, M.; Li, Y.-T.; Wu, Z.-Y.; Liu, Z.-Q.; Yan, C.-W.; J. Inorg. Biochem. 2009, 103, 833.

10. Erkkila, K. E.; Odom, D. T.; Barton, J. K.; Chem. Rev. 1999, 99, 2777.

11. Zhang, Q. L.; Liu, J. G.; Liu, J.; Xue, G.-Q.; Li, H.; Liu, J.-Z.; Zhou, H.; Qu, L.-H.; Ji, L.-N.; J. Inorg. Biochem. 2001, 85, 291.

12. Xu, H.; Zheng, K. C.; Chen, Y.; Li, Y. Z.; Lin, L. J.; Li, H.; Zhang, P. X.; Ji, L. N.; Dalton Trans. 2003, 2260.

13. Ensafi, A. A.; Hajian, R.; Ebrahimi. S.; J. Braz. Chem. Soc. 2009, 20, 266.

14. Howe-Grant, M.; Lippard, S. J.; Biochemistry 1979, 18, 5762.

15. Zeglis, B. M.; Pierre, V. C.; Barton, J. K.; Chem. Commun. 2007, 4565.

16. Şakıyan, İ.; Transition Met. Chem. 2007, 32, 131.

17. Nielsen, F. H. In Modern Nutrition in Health and Disease; Shils, M.; Olson, J. A.; Shike, M.; Ross, A. C., eds.; Williams \& Wilkins: Baltimore, 1999.

18. Leach, R. M.; Harris, E. D. In Handbook of Nutritionally Essential Minerals; O’Dell, B. L.; Sunde, R. A., eds.; Marcel Dekker, Inc: New York, 1997.

19. Bernadou, J.; Pratviel, G.; Bennis, F.; Girardet, M.; Meunier, B.; Biochemistry 1989, 28, 7268.

20. Gravert, D. J.; Griffin, J. H.; J. Org. Chem. 1993, 58, 820.

21. Peng, B.; Zhou, W.-H.; Yan, L.; Liu, H.-W.; Zhu, L.; Transition Met. Chem. 2009, 34, 231.

22. Xu, Z.-D.; Liu, H.; Xiao, S.-L.; Yang, M.; Bu, X.-H.; J. Inorg. Biochem. 2002, 90, 79.

23. Xu, Z.-D.; Liu, H.; Min, W.; Xiao, S.-L.; Yang, M.; Bu, X.-H.; J. Inorg. Biochem. 2002, 92, 149.

24. Bruker; SMART, SAINT, SADABS and SHELXTL; Bruker AXS Inc.: Madison, Wisconsin, USA, 1999.

25. Sheldrick, G. M.; SHELXS-97 and SHELXL-97, Program for
Crystal Structure Analysis; University of Göttingen: Göttingen, Germany, 1997.

26. Marmur, J.; J. Mol. Biol. 1961, 3, 208.

27. Reichmann, M. E.; Rice, S. A.; Thomas, C. A.; Doty, P.; J. Am. Chem. Soc. 1954, 76, 3047.

28. Liu, C.-S.; Sañudo, E. C.; Yan, L.-F.; Chang, Z.; Wang, J.-J.; Hu, T.-L.; Transition Met. Chem. 2009, 34, 51.

29. Zhu, Y.-M.; Li, W.-J.; Lv, L.-F.; Wang, P.; Wu, J.-Y.; Yang, J.-X.; Zhou, H.-P.; Tian, Y.-P.; Jiang, M.-H.; Tao, X.-T.; Transition Met. Chem. 2007, 32, 967.

30. Sain, S.; Maji, T. K.; Chaudhuri, N. R.; Transition Met. Chem. 2002, 27, 716 .

31. Amabilino, D. B.; Stoddart, J. F.; Chem. Rev. 1995, 95, 2725.

32. Claessens, C. G.; Stoddart, J. F.; J. Phys. Org. Chem. 1997, 10, 254.

33. Roesky, H. W.; Andruh, M.; Coord. Chem. Rev. 2003, 236, 91.

34. Terrín, A.; Fiol, J. J.; García-Raso, A.; Barcelí-Oliver, M.; Moreno, V.; Coord. Chem. Rev. 2007, 25, 1973.

35. Dong, F.-Y.; Li, Y.-T.; Wu, Z.-Y.; Sun, Y.-M.; Sun, W.; Liu, Z.-Q.; Song, Y.-L.; J. Inorg. Organomet. Polym. 2008, 18, 398.

36. Dou, J. M.; Gao, X. K.; Dong, F. Y.; Li, D. C.; Wang, D. Q.; Dalton Trans. 2004, 2918.

37. Sun, Y.-M.; Dong, F.-Y.; Wang, D.-Q.; Wang, Y.-L.; Li, Y.-T.; Dou, J.-M.; J. Inorg. Organomet. Polym. 2010, 20, 168.

38. Janiak, C. A.; J. Chem. Soc., Dalton Trans. 2000, 3885.

39. Hunter, C. A.; Sanders, J. K. M.; J. Am. Chem. Soc. 1990, 112, 5525.

40. Rowland, R. S.; Taylor, R.; J. Phys. Chem. 1996, 100, 7384.

41. Desiraju, G. R.; Acc. Chem. Res. 1996, $29,441$.

42. Saenger, W.; Nature 1979, 279, 343.

43. Tabassum, S.; Parveen, S.; Arjmand, F.; Acta Biomaterialia 2005, 1, 677.

44. Long, E. C.; Barton, J. K.; Acc. Chem. Res. 1990, 23, 271.

45. Pyle, A. M.; Rehmann, J. P.; Meshoyrer, R.; Kumar, C. V.; Turro, N. J.; Barton, J. K.; J. Am. Chem. Soc. 1989, 111, 3051.

46. Peng, B.; Chao, H.; Sun, B.; Li, H.; Gao, F.; Ji, L.-N.; J. Inorg. Biochem. 2007, 101, 404.

47. Mesmaeker, A. K.-D.; Orellana, G.; Barton, J. K.; Turro, N. J.; Photochem. Photobiol. 1990, 52, 461.

48. Baguley, B. C.; LeBret, M.; Biochemistry 1984, 23, 937.

49. Kumar, R. S.; Arunachalam, S.; Polyhedron 2007, 26, 3255.

50. Lakowicz, J. R.; Webber, G.; Biochemistry 1973, 12, 4161. 


\title{
Crystal Structure, Supramolecular Self-Assembly and Interaction with DNA of a Mixed Ligand Manganese(II) Complex
}

\author{
Yun-Ming Sun, ${ }^{a}$ Feng-Ying Dong, ${ }^{*, a, b}$ Da-Qi Wang ${ }^{c}$ and Yan-Tuan Li $^{b}$ \\ ${ }^{a}$ College of Chemistry and Pharmacy, Qingdao Agricultural University, Qingdao, Shandong, \\ 266109, People's Republic of China \\ ${ }^{b}$ Marine Drug \& Food Institute, Ocean University of China, 5 Yushan Road, Qingdao, Shandong, \\ 266003, People's Republic of China \\ ${ }^{c}$ College of Chemistry and Chemical Engineering, Liaocheng University, Liaocheng, Shandong, \\ 252059, People's Republic of China
}

Table S1. Summary of crystallographic data for complex 1

\begin{tabular}{lc}
\hline Empirical formula & $\mathrm{C}_{31} \mathrm{H}_{21} \mathrm{ClMnN}_{4} \mathrm{O}_{6}$ \\
Color/shape & Orange/block \\
Formula weight & 635.91 \\
Crystal size / mm & $0.40 \times 0.29 \times 0.21$ \\
Temperature / K & $298(2)$ \\
Crystal system & Monoclinic \\
Space group & $P 2_{1} / \mathrm{n}$ \\
a / $\AA$ & $16.8160(19)$ \\
$\mathrm{b} / \AA$ & $10.6303(15)$ \\
$\mathrm{c} / \AA$ & $16.934(2)$ \\
$\beta$ / degree & $113.134(2)$ \\
$\mathrm{V} / \AA \AA^{3}$ & $2783.6(6)$ \\
$\mathrm{Z}$ & 4 \\
$\mathrm{D}_{\text {calc }} /(\mathrm{g}$ cm & -3 \\
Absorption coefficient / $\left(\mathrm{mm}^{-1}\right)$ & 1.517 \\
Absorption correction & 0.624 \\
Max. and min. transmission & $\mathrm{SADABS}$ \\
Data/restraints/parameters & 0.8802 and 0.7885 \\
$\mathrm{~F}(000)$ & $4887 / 0 / 388$ \\
Theta range / degree & 1300 \\
Reflection collected & 1.45 to 25.01 \\
Independent reflections & 13646 \\
Goodness-of-fit on $F^{2}$ & 4887 \\
$\mathrm{R}_{1}, w \mathrm{R}_{2}[\mathrm{I}>2 \sigma(\mathrm{I})]$ & 1.003 \\
Largest diff. peak and hole / $\left(\mathrm{e} \AA^{-3}\right)$ & $0.0604,0.1508$ \\
\hline & $0.510,-0.360$ \\
\hline
\end{tabular}

Table S2. Selected bond lengths $(\AA)$ and angles $\left(^{\circ}\right)$ for complex 1

\begin{tabular}{lccc}
\hline $\mathrm{Mn}(1)-\mathrm{O}(2)$ & $2.057(4)$ & $\mathrm{Mn}(1)-\mathrm{N}(4)$ & $2.234(5)$ \\
$\mathrm{Mn}(1)-\mathrm{O}(1)$ & $2.158(4)$ & $\mathrm{Mn}(1)-\mathrm{N}(1)$ & $2.264(4)$ \\
$\mathrm{Mn}(1)-\mathrm{N}(3)$ & $2.227(5)$ & $\mathrm{Mn}(1)-\mathrm{N}(2)$ & $2.346(5)$ \\
$\mathrm{O}(2)-\mathrm{Mn}(1)-\mathrm{O}(1)$ & $84.12(16)$ & $\mathrm{N}(1)-\mathrm{Mn}(1)-\mathrm{N}(2)$ & $71.69(17)$ \\
$\mathrm{O}(2)-\mathrm{Mn}(1)-\mathrm{N}(3)$ & $91.89(16)$ & $\mathrm{O}(1)-\mathrm{Mn}(1)-\mathrm{N}(1)$ & $102.47(17)$ \\
$\mathrm{O}(1)-\mathrm{Mn}(1)-\mathrm{N}(3)$ & $160.36(17)$ & $\mathrm{N}(3)-\mathrm{Mn}(1)-\mathrm{N}(1)$ & $96.62(16)$ \\
$\mathrm{O}(2)-\mathrm{Mn}(1)-\mathrm{N}(4)$ & $113.54(16)$ & $\mathrm{N}(4)-\mathrm{Mn}(1)-\mathrm{N}(1)$ & $155.92(17)$ \\
$\mathrm{O}(1)-\mathrm{Mn}(1)-\mathrm{N}(4)$ & $90.1(2)$ & $\mathrm{O}(2)-\mathrm{Mn}(1)-\mathrm{N}(2)$ & $159.07(16)$ \\
$\mathrm{N}(3)-\mathrm{Mn}(1)-\mathrm{N}(4)$ & $73.81(19)$ & $\mathrm{O}(1)-\mathrm{Mn}(1)-\mathrm{N}(2)$ & $93.76(16)$ \\
$\mathrm{O}(2)-\mathrm{Mn}(1)-\mathrm{N}(1)$ & $88.39(16)$ & $\mathrm{N}(3)-\mathrm{Mn}(1)-\mathrm{N}(2)$ & $96.62(16)$ \\
$\mathrm{N}(4)-\mathrm{Mn}(1)-\mathrm{N}(2)$ & $87.24(17)$ & $\mathrm{C}(3)-\mathrm{O}(2)-\mathrm{Mn}(1)$ & $130.9(3)$ \\
\hline
\end{tabular}

*e-mail: dfy1972@163.com 
Table S3. Data of $\pi-\pi$ stacking interactions in complex $\mathbf{1}^{\mathrm{a}, \mathrm{b}, \mathrm{c}, \mathrm{d}}$

\begin{tabular}{|c|c|c|c|c|c|c|c|c|}
\hline Stacking moieties (mode) & $\mathrm{h}$ & $\alpha$ & $\mathrm{r}$ & $\theta$ & d & A & $\mathrm{B}$ & $\mathrm{C}$ \\
\hline \multirow[t]{3}{*}{ N4-phen and N4A-phen (I) } & 3.520 & 0 & 1.23 & 19.32 & $\mathrm{~A}^{\prime}$ & 6.450 & 4.801 & 3.849 \\
\hline & & & & & $\mathrm{B}^{\prime}$ & 4.801 & 3.995 & 3.629 \\
\hline & & & & & $C^{\prime}$ & 3.849 & 3.629 & 4.667 \\
\hline \multirow[t]{4}{*}{ N2-py and N1A-py (II) } & 3.504 & 11 & 1.44 & 22.29 & $\mathrm{~A}^{\prime}$ & 6.249 & 4.974 & 3.787 \\
\hline & & & & & $\mathrm{B}^{\prime}$ & 7.863 & 6.845 & 5.117 \\
\hline & & & & & $\mathrm{C}^{\prime}$ & 9.978 & 8.621 & 6.677 \\
\hline & & & & & \multicolumn{4}{|c|}{ short contacts } \\
\hline N3-py and C7A-ar (III) & 3.721 & 17.60 & 0.98 & 14.82 & \multicolumn{4}{|c|}{ 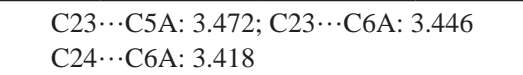 } \\
\hline C7-ar and N1A-phen (IV) & & 95.50 & & & \multicolumn{4}{|c|}{ 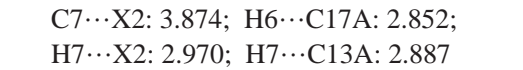 } \\
\hline
\end{tabular}

${ }^{a}$ Symmetry codes: I 2-x, 2-y,-z; II 1.5-x, 0.5+y, 0.5-z; III 0.5+x, 1.5-y, -0.5+z; IV 0.5+x, 1.5-y, 0.5+z.

${ }^{\mathrm{b}} \mathrm{N} 4-$ phen represents the N4-bound phenanthroline; N2-py represents the N2-bound pyridine moiety of phenanthroline; C7-ar represents the C7-bound arene. 'd Centroid-centroid distance $(\AA)$; h Interplanar separation $(\AA)$; $\alpha$ dihedral angle $\left(^{\circ}\right) ; \theta$ Slip angle $\left({ }^{\circ}\right) ; r$ Centroid displacement $(\AA) . \cos \theta=h / d ; r^{2}=d^{2}-h^{2}$.

${ }^{\mathrm{d}} \mathrm{A}, \mathrm{B}, \mathrm{C}, \mathrm{A}^{\prime}, \mathrm{B}^{\prime}$ and $\mathrm{C}^{\prime}$ represent the six-membered rings in two stacking phenanthroline ligands. X2 represents the centroid of phenanthroline ligand.

Table S4. A list of hydrogen bonds in complex $\mathbf{1}\left(\AA{ }^{\circ}\right)^{\mathrm{a}}$

\begin{tabular}{lcccc}
\hline $\mathrm{D}-\mathrm{H} \cdots \mathrm{A}$ & $\mathrm{D}-\mathrm{H}$ & $\mathrm{H} \cdots \mathrm{A}$ & $\mathrm{D} \cdots \mathrm{A}$ & $\angle \mathrm{DHA}$ \\
\hline $\mathrm{C} 1-\mathrm{H} 1 \cdots \mathrm{O} 5 \# 1$ & 0.93 & 2.59 & 3.22 & 155 \\
$\mathrm{C} 8-\mathrm{H} 8 \cdots \mathrm{O} 2$ & 0.93 & 2.55 & 3.12 & 120 \\
$\mathrm{C} 10-\mathrm{H} 10 \cdots \mathrm{O} 1 \# 2$ & 0.93 & 2.55 & 3.32 & 141 \\
$\mathrm{C} 31-\mathrm{H} 31 \cdots \mathrm{O} 2 \# 3$ & 0.93 & 2.53 & 3.19 & 128 \\
$\mathrm{C} 22-\mathrm{H} 22 \cdots \mathrm{O} 3 \# 4$ & 0.93 & 2.69 & 3.44 & 138 \\
$\mathrm{C} 29-\mathrm{H} 29 \cdots \mathrm{O} 3 \# 5$ & 0.93 & 2.66 & 3.38 & 135 \\
\hline
\end{tabular}

a Symmetry codes: \#1 $0.5-\mathrm{x}, 0.5+\mathrm{y}, 0.5-\mathrm{z} ; \# 2$ 1.5-x, $-0.5+\mathrm{y}, 0.5-\mathrm{z}$;

\#3 1-x, 1-y, 1-z; \#4 1+x, 1+y, z; \#5 1-x, 1-y, -z. 